\title{
PANCASILA SEBAGAI NORMA DASAR DALAM SISTEM HUKUM INDONESIA
}

\author{
Fransiska Novita Eleanora \\ FH MPU Tantular Jakarta \\ Email : vita_eleanor@yahoo.com
}

\begin{abstract}
Absract
Pancasila is the ideological basis for the country Indonesia, the name consists of two words from Sanskrit: penta meaning five and precepts means principle or principles. The principle's is the formulation and guidelines of national and state for all Indonesian people. Principle's as the state and national ideology took the logical consequence that the values of principle's is premised basic, fundamental basis for the holding of the Indonesian state. The research method is literature study, the aim is to find out how the functions of principle's as the basic norm in the legal system of Indonesia. The result is that the principle's as the basic norm is the visibility of the nation is reflected in the 5 principle's.
\end{abstract}

Key Words : Principle, Basic norms, legal system

\begin{abstract}
Abstrak
Pancasila adalah ideologi dasar bagi negara Indonesia, nama ini terdiri dari dua kata dari bahasa sansekerta : pañca berarti lima dan śíla berarti prinsip atau asas. Pancasila merupakan rumusan dan pedoman kehidupan berbangsa dan bernegara bagi seluruh rakyat Indonesia. Pancasila sebagai dasar negara dan ideologi nasional membawa konsekuensi logis bahwa nilai-nilai pancasila dijadikan landasan pokok, landasan fundamental bagi penyelenggaraan negara Indonesia. Metode penelitian adalah studi kepustakaan, tujuannya adalah untuk mengetahui bagaimana fungsi pancasila sebagai norma dasar dalam sistem hukum Indonesia. Hasilnya adalah bahwa pancasila sebagai norma dasar merupakan pandangan hidup bangsa yang tercermin dalam 5 (sila) dalam pancasila.
\end{abstract}

Kata Kunci : Pancasila, Norma dasar, Sistem hukum

\section{A. PENDAHULUAN}

Pancasila sebagai ideologi berhakikat sebagai sistem nilai bangsa Indonesia. Sistem nilai seperti ini dipandang oleh studi filsafat yang secara historik digali pada budaya bangsa dan ditempa oleh penjajahan, yang kemudian diterapkan pada wilayah yuridiskenegaraan sebagai pedoman bermoral, berhukum, dan berpolitik dalam kehidupan bermasyarakat, berbangsa, dan bernegara. 
Upaya mewujudkan Pancasila sebagai sumber nilai adalah dijadikannya nilai nilai dasar menjadi sumber bagi penyusunan norma hukum di Indonesia. Operasionalisasi dari nilai dasar pancasila itu adalah dijadikannya pancasila sebagai norma dasar bagi penyusunan norma hukum di Indonesia. Negara Indonesia memiliki hukum nasional yang merupakan satu kesatuan sistem hukum.

Sistem hukum Indonesia itu bersumber dan berdasar pada pancasila sebagai norma dasar bernegara. Pancasila berkedudukan sebagai grundnorm (norma dasar) atau staatfundamentalnorm (norma fondamental negara) dalam jenjang norma hukum di Indonesia.

Nilai-nilai pancasila selanjutnya dijabarkan dalam berbagai peraturan perundangam yang ada. Perundang-undangan, ketetapan, keputusan, kebijaksanaan pemerintah, program-program pembangunan, dan peraturanperaturan lain pada hakikatnya merupakan nilai instrumental sebagai penjabaran dari nilai-nilai dasar pancasila. ${ }^{1}$

Kedudukan pancasila sebagai dasar negara dalam pembukaan UUD $1945 \mathrm{ini}$ bersifat yuridis - konstitusional. Artinya nilai pancasila sebagai norma dasar negara (Grundnorm, kaidah negara yang fundamental) bersifat imperatif ; artinya mengikat dan memaksa semua yang ada didalam wilayah kekuasaan hokum negara RI untuk setia melaksanakan, mewariskan, mengmbangkan dan melestarikannya.

Pancasila sebagai dasar - dasar filosofis terdapat dalam Pembukaan UUD 1945 yang merupakan kesepakatan pertama penyangga konstitusionalisme. Dengan tidak diubahnya Pembukaan UUD 1945, maka tidak berubah pula kedudukan pancasila sebagai dasar - dasar filosofis bangunan negara republik Indonesia, yang berubah adalah sistem dan institusi untuk mewujudkan cita-cita berdasarkan nilai-nilai pancasila dan perkembangan masyarakat.

Pancasila mengakui dan melindungi baik hak-hak individu maupun hak masyarakat baik di bidang ekonomi maupun politik. Dengan demikian ideologi kita mengakui secara selaras baik kolektivisme maupun individualisme. Tujuan

\footnotetext{
${ }^{1}$ Fahrul Ihsan, Ekonomi Pancasila : Gagasan Dan Kemungkinan, Pusataka LP3ES, Jakarta, hal. 51
} 
dari penulisan ini adalah untuk mengetahui bagaimana kedudukan dan fungsi pancasila di dalam sistem hukum Indonesia.

\section{B. PEMBAHASAN}

\section{Pancasila Sebagai Pandangan Hidup Bangsa}

Pandangan Hidup adalah Konsep atau cara pandang manusia yang bersifat mendasar tentang diri dan dirinya. Pandangan hidup berarti pendapat atau pertimbangan yang dijadikan pegangan, pedoman, arahan, petunjuk hidup didunia. Pendapat atau pertimbangan itu merupakan hasil pemikiran manusia berdasarkan pengalaman sejarah berdasarkan waktu dan lingkungan hidupnya. ${ }^{2}$

Pandangan hidup bukanlah timbul seketika ataupun dalam waktu yang singkat, melainkan dalam waktu yang lama dan proses terus menerus sehingga hasil pemikiran tersebut dapat di uji kenyataannya, serta dapat diterima oleh akal dan diakui kebenarannya. Dan atas dasar tersebut manusia menerima hasil pemikiran itu sebagai pegangan, pedoman, arahan, atau petunjuk yang dapat disebut sebagai pandangan hidup

Pancasila Sebagai Pandangan Hidup Bangsa Indonesia. Sebagaimana yang ditujukan dalam ketetapan MPR No. II/MPR/1979, maka Pancasila itu adalah jiwa seluruh rakyat Indonesia, pandangan hidup bangsa Indonesia dan dasar negara kita. Setiap bangsa yang ingin berdiri kokoh dan mengetahui dengan jelas arah serta tujuan yang ingin dicapainya sangat memerlukan nilai-nilai luhur yang dijunjung sebagai pandangan / filsafat hidup.

Dalam pergaulan hidup terkandung konsep dasar mengenai kehidupan yang dicita - citakan oleh suatu bangsa, terkandung pikiran - pikiran yang terdalam dan gagasan suatu bangsa mengenai wujud kehidupan yang dianggap baik. Dengan demikian, pancasila sebagai pandangan hidup bangsa Indonesia juga harus berdasarkan pada Bhineka Tunggal Ika yang merupakan asas pemersatu bangsa sehingga tidak boleh mematikan keanekaragaman. ${ }^{3}$

Hakekat Bhineka Tunggal Ika sebagai perumusan dalam salah satu penjabaran arti dan makna Pancasila menurut Notonegoro adalah bahwa

${ }^{3}$ Misbah Ulmunir, Pendidikan Pancasila, Paradigma, Yogyakarta, 2006, hal. 11 
perbedaan itu adalah kodrat bawaan manusia sebagai makhluk Tuhan Yang Maha Esa, namun perbedaan itu bukan untuk dipertentangkan dan diperuncingkan melainkan perbedaan itu untuk dipersatukan, disintesakan dalam suatu sintesa yang positif dalam suatu negara kebersamaan, negara persatuan indonesia.

\section{Pancasila Sebagai Dasar Negara}

Dasar negara adalah landasan kehidupan berbangsa dan bernegara yang keberadaannya wajib dimiliki oleh setiap negara dalam setiap detail kehidupannya. Dasar negara bagi suatu negara merupakan suatu dasar untuk mengatur semua penyelenggaraan yang terbentuk dalam sebuah negara.

Negara tanpa dasar negara berarti negara tersebut tidak memiliki pedoman dalam penyelenggaraan kehidupan bernegara, maka akibatnya negara tersebut tidak memiliki arah dan tujuan yang jelas, sehingga memudahkan munculnya kekacauan. Dasar negara sebagai pedoman hidup bernegara mencakup norma bernegara, cita-cita negara, dan tujuan negara. Istilah dasar negara terbentuk dari dua kata yaitu dasar dan negara. Dalam kamus umum bahasa Indonesia, kata dasar berarti: bagian yang terbawah, alas, fundamental, dan asas pokok atau pangkal (suatu pendapat atau aturan, dsb).

Sedangkan kata negara berarti: Persekutuan bangsa dalam satu daerah yang tentu batas - batasnya yang diperintah dan diurus oleh badan pemerintahan yang teratur, dan Daerah dalam lingkungan satu pemerintah yang teratur.

Sebagai suatu konsep norma hukum tertinggi atau sumber dari segala sumber hukum dalam suatu negara yang berintikan seperangkat nilai yang bersifat menyeluruh dan mendalam sebagai fandemen yang kokoh dan kuat serta bersumber dari pandangan hidup serta cerminan dari peradaban, kebudayaan, keluhuran budi dan kepribadian yang tumbuh dalam sejarah perkembangan suatu negara dan diterima oleh seluruh lapisan masyarakat.

Pancasila sebagai sumber segala sumber hukum atau sebagai sumber tertib hukum dapat dijabarkannya suatu sistem dalam sturktur fungsi pancasila sebagai: Pancasila sebagai dasar negara adalah merupakan sumber dari segala sumber hukum (sumber tertib hukum) Indonesia. 
1. Pancasila merupakan asas kerohanian tertib hukum Indonesia yang dalam pembukaan UUD 1945 dijabarkan dalam empat pokok pikiran.

2. Mewujudkan cita - cita sebagai dasar hukum yang tertulis maupun tidak tertulis.

3. Pancasila mengandung norma yang mengharuskan UUD 1945 dengan isi yang mewajibkan pemerintah dan penyelenggara negara yang lain termasuk para penyelenggara partai dan golongan fungsional memegang teguh cita-cita rakyat yang bermoral luhur.

4. Pancasila sebagi sumber semangat kebangsaan bagi UUD 1945, penyelenggara negara, pelaksana pemerintah, termasuk penyelenggara parati dan golongan fungsional.

\section{Pancasila Sebagai Sistem Filsafat}

Pancasila digali dari nilai-nilai sosio-budaya bangsa Indonesia dan diperkaya oleh nilai-nilai dan masukan pengalaman bangsa-bangsa lain. Pancasila adalah weltanschauung (way of life) bangsa Indonesia. Uniknya, nilai-nilai Pancasila yang bertumbuh kembang sebagai kepribadian bangsa itu merupakan filsafat sosial yang wajar (natural social philosophy). Nilai-nilai itu bukan hasil pemikiran tunggal atau suatu ajaran dari siapa pun.

Lazim dipahami setelah menjadi konsensus nasional dan ditetapkan sebagai dasar negara (filsafat negara) Republik Indonesia, Pancasila adalah pedoman sekaligus cita - cita bersama dalam kehidupan bermasyarakat, berbangsa dan bernegara. Secara formal, yuridis - konstitusional, kedudukan dan fungsi Pancasila sebagai dasar negara bersifat imperatif. Namun, kita juga menyadari bahwa pengamalannya dalam keseharian hidup bermasyarakat, berbangsa dan bernegara masih akan selalu menghadapi berbagai ancaman, tantangan, hambatan dan gangguan.

Dalam era kesemrawutan global sekarang, ideologi asing mudah bermetamorfosa dalam aneka bentuknya dan menjadi pesaing Pancasila. Hedonisme (aliran yang mengutamakan kenikmatan hidup) dan berbagai isme penyerta, misalnya, semakin terasa menjadi pesaing yang membahayakan 
potensialitas Pancasila sebagai kepribadian bangsa. Nilai intrinsik Pancasila pun masih sangat dipengaruhi oleh berbagai faktor kondisional. Padahal, gugatan terhadap Pancasila sebagai dasar negara dengan sendirinya akan menjadi gugatan terhadap esensi dan eksistensi kita sebagai manusia dan warga bangsa dan negara Indonesia.

Untuk menghadapi kedua ekstrim (memandang nilai-nilai Pancasila terlalu sulit dilaksanakan oleh segenap bangsa Indonesia di satu pihak dan di pihak lain memandang nilai-nilai Pancasila kurang efektif untuk memperjuangkan pencapaian masyarakat adil dan makmur yang diidamkan seluruh bangsa Indonesia) diperlukan usaha bersama yang tak kenal lelah guna menghayati Pancasila sebagai warisan budaya bangsa yang bernilai luhur, suatu sistem filsafat yang tidak bertentangan dengan nilai-nilai agama, bersifat normatif dan ideal, sehingga pengamalannya merupakan tuntutan batin dan nalar setiap manusia Indonesia. Oeh karena itu Pancasila sebagai system filsafat dapat ditinjau dari 3 (tiga) Aspek, yakni : Aspek Ontologis, Aspek Epistemologis dan Aspek Aksiologis

\section{(1) Aspek Ontologis}

Penyelidikan hakikat ada (esensi) dan keberadaan (eksistensi) segala sesuatu : alam semesta, fisik, psikis, spiritual, metafisik, termasuk kehidupan sesudah mati, dan Tuhan. Ontologi Pancasila mengandung azas dan nilai antara lain :

a. Tuhan yang mahaesa adalah sumber eksistensi kesemestaan. Ontologi ketuhanan bersifat religius, supranatural, transendental dan suprarasional;

b. Ada - kesemestaan, alam semesta (makrokosmos) sebagai ada tak terbatas, dengan wujud dan hukum alam, sumber daya alam yang merupakan prwahana dan sumber kehidupan semua makhluk: bumi, matahari, zat asam, air, tanah subur, pertambangan, dan sebagainya;

c. Eksistensi subyek / pribadi manusia: individual, suku, nasional, umat manusia (universal). Manusia adalah subyek unik dan mandiri baik personal maupun nasional, merdeka dan berdaulat. Subyek pribadi mengemban identitas unik: menghayati hak dan kewajiban dalam kebersamaan dan kesemestaan (sosial - horisontal dengan alam dan sesama 
manusia), sekaligus secara sosial - vertikal universal dengan Tuhan. Pribadi manusia bersifat utuh dan unik dengan potensi jasmani - rohani, karya dan kebajikan sebagai pengemban amanat keagamaan;

d. Eksistensi tata budaya, sebagai perwujudan martabat dan kepribadian manusia yang unggul. Baik kebudayaan nasional maupun universal adalah perwujudan martabat dan kepribadian manusia: sistem nilai, sistem kelembagaan hidup seperti keluarga, masyarakat, organisasi, negara. Eksistensi kultural dan peradaban perwujudan teleologis manusia: hidup dengan motivasi dan cita - cita sehingga kreatif, produktif, etis, berkebajikan;

e. Eksistensi bangsa - negara yang berwujud sistem nasional, sistem kenegaraan yang merdeka dan berdaulat, yang menampilkan martabat, kepribadian dan kewibawaan nasional. Sistem kenegaraan yang merdeka dan berdaulat merupakan puncak prestasi perjuangan bangsa, pusat kesetiaan, dan kebanggaan nasional.

(2) Aspek Epistemologis

Sumber, proses, syarat-syarat batas, validitas dan hakikat ilmu. Epistemologi Pancasila secara mendasar meliputi nilai - nilai dan azas-azas:

a. Mahasumber ialah Tuhan, yang menciptakan kepribadian manusia dengan martabat dan potensi unik yang tinggi, menghayati kesemestaan, nilai agama dan ketuhanan. Kepribadian manusia sebagai subyek diberkati dengan martabat luhur: pancaindra, akal, rasa, karsa, cipta, karya dan budi nurani. Kemampuan martabat manusia sesungguhnya adalah anugerah dan amanat ketuhanan / keagamaan.

b. Sumber pengetahuan dibedakan dibedakan secara kualitatif, antara:

c. Sumber primer, yang tertinggi dan terluas, orisinal: lingkungan alam, semesta, sosial - budaya, sistem kenegaraan dan dengan dinamikanya;

d. Sumber sekunder: bidang-bidang ilmu yang sudah ada / berkembang, kepustakaan, dokumentasi;

e. Sumber tersier: cendekiawan, ilmuwan, ahli, narasumber, guru. 
f. Wujud dan tingkatan pengetahuan dibedakan secara hierarkis: atas Pengetahuan indrawi, Pengetahuan Ilmiah, Pengetahuan filosofis dan Pengetahuan Religius.

g. Pengetahuan manusia relatif mencakup keempat wujud tingkatan itu. Ilmu adalah perbendaharaan dan prestasi individual maupun sebagai karya dan warisan budaya umat manusia merupakan kualitas martabat kepribadian manusia. Perwujudannya adalah pemanfaatan ilmu guna kesejahteraan manusia, martabat luhur dan kebajikan para cendekiawan (kreatif, sabar, tekun, rendah hati, bijaksana). Ilmu membentuk kepribadian mandiri dan matang serta meningkatkan harkat martabat pribadi secara lahiriah, sosial (sikap dalam pergaulan), psikis (sabar, rendah hati, bijaksana). Ilmu menjadi kualitas kepribadian, termasuk kegairahan, keuletan untuk berkreasi dan berkarya.

h. Martabat kepribadian manusia dengan potensi uniknya memampukan manusia untuk menghayati alam metafisik jauh di balik alam dan kehidupan, memiliki wawasan kesejarahan (masa lampau, kini dan masa depan), wawasan ruang (negara, alam semesta), bahkan secara suprarasional menghayati Tuhan yang supranatural dengan kehidupan abadi sesudah mati. Pengetahuan menyeluruh ini adalah perwujudan kesadaran filosofis-religius, yang menentukan derajat kepribadian manusia yang luhur. Berilmu / berpengetahuan berarti mengakui ketidaktahuan dan keterbatasan manusia dalam menjangkau dunia suprarasional dan supranatural. Tahu secara 'melampaui tapal batas' ilmiah dan filosofis itu justru menghadirkan keyakinan religius yang dianut seutuh kepribadian: mengakui keterbatasan pengetahuan ilmiah-rasional adalah kesadaran rohaniah tertinggi yang membahagiakan.

\section{(3) Aspek Aksiologis}

Menyelidiki pengertian, jenis, tingkatan, sumber dan hakikat nilai secara kesemestaan. Aksiologi Pancasila pada hakikatnya sejiwa dengan ontologi dan epistemologinya. Pokok - pokok aksiologi itu dapat disarikan sebagai berikut: 
a. Tuhan yang mahaesa sebagai mahasumber nilai, pencipta alam semesta dan segala isi beserta antarhubungannya, termasuk hukum alam. Nilai dan hukum moral mengikat manusia secara psikologis - spiritual: akal dan budi nurani, obyektif mutlak menurut ruang dan waktu secara universal. Hukum alam dan hukum moral merupakan pengendalian semesta dan kemanusiaan yang menjamin multieksistensi demi keharmonisan dan kelestarian hidup.

b. Subyek manusia dapat membedakan hakikat mahasumber dan sumber nilai dalam perwujudan Tuhan yang mahaesa, pencipta alam semesta, asal dan tujuan hidup manusia (sangkan paraning dumadi, secara individual maupun sosial).

c. Nilai-nilai dalam kesadaran manusia dan dalam realitas alam semesta yang meliputi: Tuhan yang mahaesa dengan perwujudan nilai agama yang diwahyukan-Nya, alam semesta dengan berbagai unsur yang menjamin kehidupan setiap makhluk dalam antarhubungan yang harmonis, subyek manusia yang bernilai bagi dirinya sendiri (kesehatan, kebahagiaan, etc.) beserta aneka kewajibannya. Cinta kepada keluarga dan sesama adalah kebahagiaan sosial dan psikologis yang tak ternilai. Demikian pula dengan ilmu, pengetahuan, sosio-budaya umat manusia yang membentuk sistem nilai dalam peradaban manusia menurut tempat dan zamannya

d. Manusia dengan potensi martabatnya menduduki fungsi ganda dalam hubungan dengan berbagai nilai: manusia sebagai pengamal nilai atau 'konsumen' nilai yang bertanggung jawab atas norma-norma penggunaannya dalam kehidupan bersama sesamanya, manusia sebagai pencipta nilai dengan karya dan prestasi individual maupun sosial (ia adalah subyek budaya). "Man created everything from something to be something else, God created everything from nothing to be everything." Dalam keterbatasannya, manusia adalah prokreator bersama Allah.

e. Martabat kepribadian manusia secara potensial-integritas bertumbuh kembang dari hakikat manusia sebagai makhluk individu-sosial-moral: 
berhikmat kebijaksanaan, tulus dan rendah hati, cinta keadilan dan kebenaran, karya dan darma bakti, amal kebajikan bagi sesama.

f. Manusia dengan potensi martabatnya yang luhur dianugerahi akal budi dan nurani sehingga memiliki kemampuan untuk beriman kepada Tuhan yang mahaesa menurut agama dan kepercayaan masing-masing. Tuhan dan nilai agama secara filosofis bersifat metafisik, supernatural dan supranatural. Maka potensi martabat manusia yang luhur itu bersifat apriori: diciptakan Tuhan dengan identitas martabat yang unik: secara sadar mencintai keadilan dan kebenaran, kebaikan dan kebajikan. Cinta kasih adalah produk manusia - identitas utama akal budi dan nuraninya - melalui sikap dan karyanya.

g. Manusia sebagai subyek nilai memikul kewajiban dan tanggung jawab terhadap pendayagunaan nilai, mewariskan dan melestarikan nilai dalam kehidupan. Hakikat kebenaran ialah cinta kasih, dan hakikat ketidakbenaran adalah kebencian (dalam aneka wujudnya: dendam, permusuhan, perang, etc.).

h. Eksistensi fungsional manusia ialah subyek dan kesadarannya. Kesadaran berwujud dalam dunia indra, ilmu, filsafat (kebudayaan/ peradaban, etika dan nilai-nilai ideologis) maupun nilai-nilai supranatural.

\section{Pancasila Sebagai Ideologi Bangsa Indonesia}

Ideologi berasal dari kata 'idea' = gagasan, konsep, pengertian dasar, citacita. ' $\log o s$ '= ilmu. Kata idea berasal dari kata bahasa Yunani 'eidos'=bentuk. 'Idein'= melihat. Secara harfiah, Ideologi adalah ilmu pengetahuan tentang ideide (the science of ideas), atau ajaran tentang pengertian-pengertian dasar.

Ideologi menurut Kamus Umum Bhs Indonesia adalah keyakinan yang dicita - citakan sebagai dasar pemerintahan negara. Sedangkan pengertian 'ideologi' secara umum adalah kumpulan gagasan-gagasan, ide - ide, keyakinan keyakinan, kepercayaan - kepercayaan yang menyeluruh dan sistematis, yang menyangkut dan mengatur tingkah laku sekelompok manusia tertentu dalam pelbagai bidang kehidupan yang menyangkut bidang politik (termasuk bidang 
pertahanan dan keamanan), bidang sosial, bidang kebudayaan, dan bidang keagamaan.

Di dalam Pancasila telah tertuang cita-cita, ide-ide, gagasan-gagasan yang ingin dicapai bangsa Indonesia. Oleh karena itu Pancasila dijadikan Ideologi Bangsa., dikenal 2 (dua) Ideologi, yaitu :

\section{A. Ideologi Terbuka dan Ideologi Tertutup}

Ideologi Terbuka merupakan suatu sistem pemikiran terbuka sedangkan ideologi tertutup merupakan suatu sistem pemikiran tertutup. Ciri khas Ideologi tertutup :

1. Ideologi itu bukan cita-cita yang sudah hidup dalam masyarakat, melainkan cita-cita satu kelompok orang yang mendasari suatu program untuk mengubah dan membaharui masyarakat. Hal ini berarti demi ideologi masyarakat harus berkorban untuk menilai kepercayaan ideologi dan kesetiaannya sebagai warga masyarakat.

2. Isinya bukan hanya berupa nilai-nilai dan cita-cita tertentu melainkan terdiri dari tuntutan-tuntutan konkret dan operasional yang keras.

Jadi ideologi tertutup bersifat totaliter dan menyangkut segala segi kehidupan.

Ciri khas ideologi terbuka :

1. Nilai-nilai dan cita-citanya tidak dipaksakan dari luar, melainkan digali dan diambil dari suatu kekayaan rohani, moral dan budaya masyarakat itu sendiri.

2. Dasarnya bukan keyakinan ideologis sekelompok orang, melainkan hasil musyawarah.

3. Tidak diciptakan oleh negara melainkan digali dan ditemukan masyarakat itu sendiri.

4. Isinya tidak operasional. Menjadi operasional ketika sudah dijabarkan ke dalam perangkat peraturan perundangan.

Jadi ideologi terbuka adalah milik seluruh rakyat dan masyarakat dalam menemukan dirinya, kepribadiannya di dalam ideologi tersebut. 


\section{B. Pancasila sebagai Ideologi Terbuka}

Pancasila sebagai ideologi terbuka maksudnya adalah Pancasila bersifat aktual, dinamis, antisipatif dan senantiasa mampu menyesuaikan dengan perkembangan jaman. Sebagai suatu ideologi terbuka, Pancasila memiliki dimensi :

1. Dimensi idealistis, yaitu nilai-nilai dasar yang terkandung dalam pancasila yang bersifat sistematis dan rasional yaitu hakikat nilai yang terkandung dalam lima sila Pancasila.

2. Dimensi normatif, nilai-nilai yang terkandung dalam Pancasila perlu dijabarkan dalam suatu sistem norma, sebagaimana terkandung dalam Pembukaan UUD 1945.

3. Dimensi realistis, harus mampu mencerminkan realitas yang hidup dan berkembang dalam masyarakat. Oleh karena itu Pancasila harus dijabarkan dalam kehidupan sehari - hari sehingga bersifat realistis artinya mampu dijabarkan dalam kehidupan nyata dalam berbagai bidang.

Keterbukaan Pancasila dibuktikan dengan keterbukaan dalam menerima budaya asing masuk ke Indonesia selama budaya asing itu tidak melanggar nilai-nilai yang terkandung dalam lima sila Pancasila. Misalnya masuknya budaya India, Islam, barat dan sebagainya.

\section{Pancasila Sebagai Sumber Nilai}

Nilai dasar Pancasila adalah nilai ketuhanan, nilai Kemanusiaan, nilai Persatuan, nilai Kerakyatan, dan nilai Keadilan.

\section{Makna Nilai dalam Pancasila}

\section{a. Nilai Ketuhanan Nilai Ketuhanan Yang Maha Esa}

Mengandung arti adanya pengakuan dan keyakinan bangsa terhadap adanya Tuhan sebagai pancipta alam semesta. Dengan nilai ini menyatakan bangsa Indonesia merupakan bangsa yang religius bukan bangsa yang ateis. Nilai ketuhanan juga memilik arti adanya pengakuan akan kebebasan untuk memeluk agama, menghormati kemerdekaan 
beragama, tidak ada paksaan serta tidak berlaku diskriminatif antarumat beragama.

\section{b. Nilai Kemanusiaan Yang Adil Dan Beradab}

mengandung arti kesadaran sikap dan perilaku sesuai dengan nilai-nilai moral dalam hidup bersama atas dasar tuntutan hati nurani dengan memperlakukan sesuatu hal sebagaimana mestinya.

\section{c. Nilai Persatuan Indonesia}

mengandung makna usaha ke arah bersatu dalam kebulatan rakyat untuk membina rasa nasionalisme dalam Negara Kesatuan Republik Indonesia. Persatuan Indonesia sekaligus mengakui dan menghargai sepenuhnya terhadap keanekaragaman yang dimiliki bangsa indonesia..

d. Nilai Kerakyatan Yang Dipimpin Oleh Hikmat kebijaksanaan Dalam Permusyawaratan / Perwakilan

mengandung makna suatu pemerintahan dari rakyat, oleh rakyat, dan untuk rakyat dengan cara musyawarah mufakat melalui lembaga-lembaga perwakilan.

\section{e. Nilai Keadilan Sosial Bagi Seluruh Rakyat Indonesia}

mengandung makna sebagai dasar sekaligus tujuan, yaitu tercapainya masyarakat Indonesia Yang Adil dan Makmur secara lahiriah atauun batiniah. Nilai-nilai dasar itu sifatnya abstrak dan normatif. Karena sifatnya abstrak dan normatif, isinya belum dapat dioperasionalkan. Agar dapat bersifat operasional dan eksplisit, perlu dijabarkan ke dalam nilai instrumental. Contoh nilai instrumental tersebut adalah UUD 1945 dan peraturan perundang-undangan lainnya. Sebagai nilai dasar, nilai-nilai tersebut menjadi sumber nilai. Artinya, dengan bersumber pada kelima nilai dasar diatas dapat dibuat dan dijabarkan nilai-nilai instrumental penyelenggaraan negara Indonesia. ${ }^{4}$

\section{f. Pentingnya Paradigma Dalam Pembangunan Pembangunan}

\footnotetext{
${ }^{4}$ Dardji Darmodihardjo \& Shidarta, Penjabaran Nilai-Nilai Pancasila Dalam Sistem Hukum Indonesia, PT. Raja Grafindo Persada, Jakarta, 1998. hal. 45
} 
yang sedang digalakkan memerlukan paradigma, suatu kerangka berpikir atau suatu model mengenai bagaimana hal-hal yang sangat esensial dilakukan. Pembangunan dalam perspektif Pancasila adalah pembangunan yang sarat muatan nilai yang berfungsi menajdi dasar pengembangan visi dan menjadi referensi kritik terhadap pelaksanaan pembangunan.

\section{g. Pancasila Sebagai Orientasi Dan Kerangka Acuan}

a. Pancasila sebagai Orientasi Pembangunan Pada saat ini Pancasila lebih banyak dihadapkan pada tantangan berbagai varian kapitalisme daripada komunisme atau sosialisme. Ini disebabkan perkembangan kapitalisme yang bersifat global. Fungsi Pancasila ialah memberi orientasi untuk terbentuknya struktur kehidupan social-politik dan ekonomi yang manusiawi, demokratis dan adil bagi seluruh rakyat.

\section{b. Pancasila sebagai Kerangka Acuan Pembangunan}

Pancasila diharapkan dapat menjadi matriks atau kerangka referensi untuk membangun suatu model masyarakat atau untuk memperbaharui tatanan social budaya.

\section{Nilai Pancasila Sebagai Sumber Norma Hukum}

Upaya mewujudkan Pancasila sebagai sumber nilai adalah dijadikannya nilai nilai dasar menjadi sumber bagi penyusunan norma hukum di Indonesia. Operasionalisasi dari nilai dasar pancasila itu adalah dijadikannya pancasila sebagai norma dasar bagi penyusunan norma hukum di Indonesia. Negara Indonesia memiliki hukum nasional yang merupakan satu kesatuan sistem hukum. Sistem hukum Indonesia itu bersumber dan berdasar pada pancasila sebagai norma dasar bernegara. Pancasila berkedudukan sebagai grundnorm (norma dasar) atau staatfundamentalnorm (norma fondamental negara) dalam jenjang norma hukum di Indonesia. Nilai - nilai pancasila selanjutnya dijabarkan dalam berbagai peraturan perundangam yang ada. Perundang undangan, ketetapan, keputusan, kebijaksanaan pemerintah, program-program 
pembangunan, dan peraturan - peraturan lain pada hakikatnya merupakan nilai instrumental sebagai penjabaran dari nilai-nilai dasar pancasila. ${ }^{5}$

\section{Nilai Pancasila menjadi Sumber Norma Etik}

Upaya lain dalam mewujudkan pancasila sebagai sumber nilai adalah dengan menjadikan nilai dasar Pancasila sebagai sumber pembentukan norma etik (norma moral) dalam kehidupan bermasyarakat, berbangsa, dan bernegara. Nilai-nilai pancasila adalah nilai moral. Oleh karena itu, nilai pancasila juga dapat diwujudkan kedalam norma - norma moral (etik). Norma - norma etik tersebut selanjutnya dapat digunakan sebagai pedoman atau acuan dalam bersikap dan bertingkah laku dalam kehidupan berbangsa dan bernegara. Bangsa Indonesia saat ini sudah berhasil merumuskan norma - norma etik sebagai pedoman dalam bersikap dan bertingkah laku. Norma - norma etik tersebut bersumber pada pancasila sebagai nilai budaya bangsa. Rumusan norma etik tersebut tercantum dalam ketetapan MPR No. VI/MPR/2001 tentang Etika Kehidupan Berbangsa, Bernegara, dan Bermasyarakat. Ketetapan MPR No. VI/MPR/2001 tentang etika Kehidupan Berbangsa, bernegara, dan bermasyarakat merupakan penjabaran nilai-nilai pancasila sebagai pedoman dalam berpikir, bersikap, dan bertingkah laku yang merupakan cerminan dari nilai - nilai keagamaan dan kebudayaan yang sudah mengakar dalam kehidupan bermasyarakat. $^{6}$

\section{a. Etika Sosial dan Budaya}

Etika ini bertolak dari rasa kemanusiaan yang mendalam dengan menampilkan kembali sikap jujur, saling peduli, saling memahami, saling menghargai, saling mencintai, dan tolong menolong di antara sesama manusia dan anak bangsa. Senafas dengan itu juga menghidupkan kembali budaya malu, yakni malu berbuat kesalahan dan semua yang bertentangan dengan moral agama dan nilai-nilai luhur budaya bangsa. Untuk itu, perlu

\footnotetext{
${ }^{5}$ Titon Slamat Kurnia, Pengantar Sistem Hukum Indonesia, Alumni, Bandung, 2009, hal. 37

${ }^{6}$ Mulyanto, Pancasila Dasar Negara, UGM, dan Jati Diri Bangsa, PT. Ghalia Bandung, 2009, hal. 62
} 
dihidupkan kembali budaya keteladanan yang harus dimulai dan diperlihatkan contohnya oleh para pemimpin pada setiap tingkat dan lapisan masyarakat.

\section{b. Etika Pemerintahan dan Politik}

Etika ini dimaksudkan untuk mewujudkan pemerintahan yang bersih, efisien, dan efektif; menumbuhkan suasana politik yang demokratis yang bercirikan keterbukaan, rasa tanggung jawab, tanggap akan aspirasi rakyat; menghargai perbedaan; jujur dalam persaingan; ketersediaan untuk menerima pendapat yang lebih benar walau datang dari orang per orang ataupun kelompok orang; serta menjunjung tinggi hak asasi manusia. Etika pemerintahan mengamanatkan agar para pejabat memiliki rasa kepedulian tinggi dalam memberikan pelayanan kepada publik, siap mundur apabila dirinya merasa telah melanggar kaidah dan sistem nilai ataupun dianggap tidak mampu memenuhi amanah masyarakat, bangsa, dan negara. ${ }^{7}$

\section{c. Etika Ekonomi dan Bisnis}

Etika ekonomi dan bisnis dimaksudkan agar prinsip dan perilaku ekonomi, baik oleh pribadi, institusi maupun pengambil keputusan dalam bidang ekonomi, dapat melahirkan kiondisi dan realitas ekonomi yang bercirikan persaingan yang jujur, berkeadilan, mendorong berkembangnya etos kerja ekonomi, daya tahan ekonomi dan kemampuan bersaing, serta terciptanya suasana kondusif untuk pemberdayaan ekonomi rakyat melalui usaha usaha bersama secara berkesinambungan. Hal itu bertujuan menghindarkan terjadinya praktik - praktik monopoli, oligopoli, kebijakan ekonomi yang bernuansa KKN ataupun rasial yang berdampak negatif terhadap efisiensi, persaingan sehat, dan keadilan; serta menghindarkan perilaku menghalalkan segala cara dalam memperoleh keuntungan.

\section{d. Etika Penegakan Hukum yang Berkeadilan}

Etika penegakan hukum dan berkeadilan dimaksudkan untuk menumbuhkan keasadaran bahwa tertib sosial, ketenangan, dan keteraturan hidup bersama 
hanya dapat diwujudkan dengan ketaatan terhadap hukum dan seluruh peraturan yang ada. Keseluruhan aturan hukum yang menjamin tegaknya supremasi hukum sejalan dengan menuju kepada pemenuha rasa keadilan yang hidup dan berkembang di dalam masyarakat.

\section{e. Etika Keilmuan dan Disiplin Kehidupan}

Etika keilmuan diwujudkan dengan menjunjung tingghi nilai-nilai ilmu pengetahuan dan teknologi agar mampu berpikir rasional, kritis, logis dan objektif. Etika ini etika ini ditampilkan secara pribadi dan ataupun kolektif dalam perilaku gemar membaca, belajar, meneliti, menulis, membahas, dan kreatif dalam menciptakan karya - karya baru, serta secara bersama-sama menciptakan iklim kondusif bagi pengembangan ilmu pengetahuan dan teknologi. Dengan adanya etika maka nilai-nilai pancasila yang tercermin dalam norma - norma etik kehidupan berbangsa dan bernegara dapat kita amalkan. Untuk berhasilnya perilaku bersandarkan pada norma-norma etik kehidupan berbangsa dan bernegara, ada beberapa hal yang perlu dilakukan sebagai berikut.

(i) Proses penanaman dan pembudayaan etika tersebut hendaknya menggunakan bahasa agama dan bahasa budaya sehingga menyentuh hati nurani dan mengundang simpati dan dukungan seluruh masyarakat. Apabila sanksi moral tidak lagi efektif, langkah - langkah penegakan hukum harus dilakukan secara tegas dan konsisten.

(ii) Proses penanaman dan pembudayaan etika dilakukan melalui pendekatan komunikatif, dialogis, dan persuasif, tidak melalui pendekatan cara indoktrinasi.

(iii) Pelaksanaan gerakan nasional etika berbangsa, bernegara, dan bermasyarakat secara sinergik dan berkesinambungan yang melibatkan seluruh potensi bangsa, pemerintah ataupun masyarakat.

(iv) Perlu dikembangkan etika - etika profesi, seperti etika profesi hukum, profesi kedokteran, profesi ekonomi, dan profesi politik yang dilandasi oleh pokok - pokok etika ini yang perlu ditaati oleh segenap anggotanya melalui kode etik profesi masing-masing 


\section{Implementasi Pancasila Sebagai Paradigma Dalam Berbagai Bidang}

1. Pancasila sebagai Paradigma Pembangunan Pendidikan Pendidikan nasional harus dipersatukan atas dasar Pancasila. Tak seyogyanya bagi penyelesaian penyelesaian masalah - masalah pendidikan nasional dipergunakan secara langsung system - sistem aliran-aliran ajaran, teori, filsafat dan praktek pendidikan berasal dari luar.

2. Pancasila sebagai Paradigma Pembangunan Ideologi Pengembangan sebagai ideologi yang memiliki dimensi realitas, idealitas dan fleksibilitas menghendaki adanya dialog yang tiada henti dengan tantangan - tantangan masa kini dan masa depan dengan tetap mengacu kepada pencapaian tujuan nasional dan cita - cita nasional Indonesia. ${ }^{8}$

3. Pancasila sebagai Paradigma Pembangunan Politik Ada perkembangan baru yang menarik berhubung dengan dasar Negara kita. Dengan kelima prinsipnya Pancasila memang menjadi dasar yang cukup integrative bagi kelompok - kelompok politik yang cukup heterogen dalam sejarah Indonesia modern.

4. Pancasila sebagai Paradigma Pembangunan Ekonomi Pembangunan ekonomi nasional harus juga berarti pembangunan system ekonomi yang kita anggap paling cocok bagi bangsa Indonesia. Dalam penyusunan system ekonomi nasional yang tangguh untuk mewujudkan masyarakat yang adil dan makmur, sudah semestinya Pancasila sebagai landasan filosofisnya.

5. Pancasila sebagai Paradigma Pembangunan Sosial-Budaya merupakan suatu kerangka di dalam suatu kelompok di dalam masyarakat dapat hidup bersama, bekerja bersama di dalam suatu dialog karya yang terus menerus guna membangun suatu masa depan bersama.

6. Pancasila sebagai Paradigma Ketahanan Sosial Perangkat nilai pada bangsa yang satu berbeda dengan perangkat nilai pada bangsa lain. Bagi bangsa Indonesia, perangkat nilai itu adalah Pancasila. Kaitan Pancasila dan

\footnotetext{
${ }^{8}$ Slamet Sutrisno, Filsafat Dan Ideologi Pancasila, Andi Publisher, Yogyakarta, 2006, hal. 28
} 
ketahanan nasional adalah kaitan antara ide yang mengakui pluralitas yang membutuhkan kebersamaan dan realitas terintegrasinya pluralitas.

7. Pancasila sebagai Paradigma Pembangunan Hukum, bukan hanya memperhatikan nilai - nilai filosofis, asas yang terkandung dalam Negara hukum, tetapi juga mempertimbangkan realitas penegakan hukum dan kesadaran hukum masyarakat.

8. Pancasila sebagai Paradigma Pembangunan Kehidupan Beragama Salah satu prasyarat terwujudnya masyarakat modern yang demokratis adalah terwujudnya masyarakat yang menghargai kemajemukan masyarakat dan bangsa serta mewujudkannya sebagai suatu keniscayaan.

9. Pancasila sebagai Paradigma Pengembangan Ilmu dan Teknologi Pancasila mengandung hal - hal yang penting dalam pengembangan ilmu dan teknologi. Perkembangan IPTEK dewasa ini dan di masa yang akan datang sangat cepat, makin menyentuh inti hayati dan materi di satu pihak, serta menggapai angkasa luas dan luar angkasa di lain pihak, lagi pula memasuki dan mempengaruhi makin dalam segala aspek kehidupan dan institusi budaya.

\section{Pancasila Dalam Sistem Hukum Indonesia}

Sistem hukum di Indonesia membentuk tata urutan peraturan perundang undangan. Tata urutan peraturan perundang - undangan sebagaimana diatur dalam ketetapan MPR No. III/MPR/2000 tentang sumber hukum dan tata urutan perundang-undangan sebagai berikut :

a. Undang - Undang Dasar 1945

b. Ketetapan Majelis Permusyawaratan Rakyat Republik Indonesia

c. Undang - undang

d. Peraturan Pemerintah Pengganti Undang - undang (Perpu)

e. Peraturan Pemerintah

f. Keputusan Presiden

g. Peraturan Daerah ${ }^{9}$

${ }^{9}$ Eka Darmaputera, Pancasila Dalam Identitas Dan Modernitas, BPK Gunung Mulia, 1997, hal. 55 
Dalam Undang - Undang No. 10 Tahun 2004 tentang pembentukan Peraturan perundang - undangan juga menyebutkan adanya jenis dan hierarki peraturan perundang - undangan sebagai berikut:

a. UUD Negara Republik Indonesia Tahun 1945.

b. Undang-undang / peraturan pemerintah pengganti undang-undang (perpu)

c. Peraturan Pemerintah

d. Peraturan Presiden

e. Peraturan Daerah

Berdasarkan ketentuan GBHN (Garis-Garis Besar Haluan Negara) tujuan pembangunan adalah mewujudkan suatu masyarakat adil dan makmur yang merata material dan spiritual berdasarkan Pancasila dan Undang - Undang Dasar 1945. GBHN 1993 menyebutkan bahwa sistem hukum nasional adalah sistem hukum yang mendukung dan bersumber pada Pancasila dan Undang - Undang Dasar 1945. Di dalam GBHN 1993 disebutkan bahwa :

"Pembangunan Hukum diarahkan pada makin terwujudnya sistem hukum nasional yang bersumber pada Pancasila dan UUD 1945 yang mencakup pembangunan ateri hukum, aparatur hukum serta sarana dan prasarana hukum dalam rangka pembangunan Negara hukum untuk menciptakan kehidupan masyarakat yang aman dan tentram. Pembangunan hukum dilaksanakan melalui pembaharuan hukum dengan tetap memperhatikan kemajemukan tatanan hukum yang berlaku yang mencakup upaya untuk meningkatkan kesdaran hukum, kepastian hukum, perlindungan hukum yang berintikan keadilan dan kebenaran, ...."

Pembangunan hukum diharapkan terwujudnya sistem hukum nasional berdasarkan Pancasila dan UUD 1945 menggantikan sistem hukum dari masa Hindia Belanda karena masih banyak peraturan dari masa itu yang masih berlaku setelah Indonesia mencapai kemerdekaannya.

Hukum nasional Indonesia adalah ketentuan-ketentuan hukum yang mengatur kehidupan manusia dalam wilayah hukum Indonesia. Sistem hukum Indonesia berdasarkan kedekatan sejarahnya adalah menganut Sistem Hukum Eropa Kontinental (Civil law). Pada sistem hukum ini dititik beratkan pada peraturan perundang-undangan yang berlaku (hukum positip). 
Hukum positip Indonesia adalah keseluruhan asas dan kaidah-kaidah berdasarkan keadilan yang mengatur hubungan manusia dalam masyarakat, yaitu berupa hubungan antar manusia, hubungan antar manusia dengan masyarakat dan sebaliknya hubungan masyarakat dengan manusia anggota masyarakat itu. Maka, hukum positip adalah sistem atau tatanan hukum dan asas-asas berdasarkan keadilan yang mengatur kehidupan manusia di masyarakat. ${ }^{10}$

\section{Asas Idiil}

Falsafah Negara, Pancasila adalah jiwa, pandangan hidup dan dasar Negara Republik Indonesia. Sebagai dasar negara, Pancasila merupakan sumber dari segala sumber hukum yang berlaku di Indonesia. Pandangan hidup adalah kristalisasi dari nilai - nilai yang dimiliki oleh suatu bangsa yang diyakini kebenarannya dan menimbulkan tekad pada bangsa itu untuk mewujudkannya. Dalam pandangan hidup ini terkandung konsep dasar mengenai kehidupan yang dicita - citakan oleh suatu bangsa. Hal ini berarti dengan berpedoman kepada pandangan hidup itu bangsa tersebut akan memecahkan persoalan - persoalan yang dihadapinya untuk memelihara identitasnya, eksistensinya, dan kelestariannya. Pancasila sebagai jiwa, pandangan hidup atau dasar Negara, bersifat abstrak dan dijabarkan ke dalam batang tubuh UUD 1945. Ketetapan-ketetapan Majelis Permusyawaratan Rakyat, yang seharusnya dikonkretisasi ke dalam aturan - aturan hukum positip. ${ }^{11}$ Melalui penjelmaan ke dalam aturan aturan-aturan hukum positip, Pancasila menyentuh kehidupan yang nyata. Didalam penjelasan Ketetapan tentang P4 (Pedoman Penghayatan dan Pengamalan Pancasila) tersebut ditunjuk asas-asas yang perlu dihayati dan diamalkan, yang merupakan pula asas-asas yang perlu diperhatikan dalam sistem hukum nasional. Asas-asas itu terkandung dalam sila-sila Pancasila, yaitu Sila Ketuhanan Yang Maha Esa, Sia Kemanusiaan Yang adil dan Beradab, Sila Persatuan Indonesia, Sila Kerakyatan yang dipimpin oleh Hikmah Kebijaksanaan dalam

\footnotetext{
10"Pancasila pandangan hidup bangsa" (http://mudiartana.blogspot.com/2010/02/pancasila-sebagaipandangan-hidup-dan.html) diakses 14 Agustus 2012

${ }^{11}$ Ilhami Bisri, Sistem Hukum Indonesia : Prinsip-Prinsip Dan Implementasi Hukum DiIndonesia, PT. Rajawali Pers, Jakarta, 2008, hal. 42
} 
Permusyawaratan Perwakilan, dan Sila Keadilan Sosial dagi Seluruh Rakyat Indonesia.

\section{Asas Konstitusional (Struktural)}

Undang-Undang Dasar 1945 terdiri dari pembukaan dan batang tubuh. Pembukaan UUD 1945 merupakan landasan filsafah dari Negara Republik Indonesia, sedangkan batang tubuh merupakan sumber-sumber hukum tertinggi dari hukum yang berlaku di Indonesia (landasan yuridisnya). Pembukaan UUD 1945 mempunyai hubungan langsung dengan batangbatang tubuh UUD 1945 itu. Hubungan langsung itu berarti keduanya merupakan satu kesatuan yang tidak dapat dipisahkan. Pokok-pokok pikiran yang dituangkan dalam Pembukaan UUD 1945 itu, keduanya mempunyai hubungan yang fungsional.

Jikalau dikaji UUD 1945 ditemukan asas-asas yang relevan dengan hukum perdata, yaitu :

"Asas-asas hukum : asas kesatuan dan persatuan, asas Negara hukum, asas persamaan, asas keadilan, asas kerakyatan, asas kemanusiaan, asas kekeluargaan, asas keseimbangan, asas kebebasan yang bertanggung jawab, asas demokrasi ekonomi, asas bhineka tunggal ika, asas kepentingan nasional, asas kepastian hukum."

Asas-asas ini bersifat abstrak (umum kolektip) oleh karena sudah menjelma di dalam hukum positip, dalam hal ini Hukum Dasar yang tertulis.

\section{Asas Politis}

Di dalam berbagai-bagai Ketetapan MPR (Majelis Permusyawaratan Rakyat) ditemukan kemauan politik tentang asas-asas yang perlu diperhatikan dalam bidang hukum perdata, seperti Ketetapan MPR II Tahun 1960. Dalam Tap MPR No.IV Tahun 1978, GBHN hasil Dalam asas politis, ada beberapa pembagian asas yang merupakan sendi dalam sistem hukum Indonesia sebagai berikut :

a) Asas manfaat, bahwa segala usaha dan kegiatan pembangunan harus dapat dimanfaatkan sebesar-besarnya bagi kemanusiaan, bagi 
peningkatan kesejahteraan rakyat dan bagi pengembangan pribadi warga negara. $^{12}$

b) Asas usaha bersama dan kekeluargaan, bahwa usaha mencapai cita-cita dan aspirasi bangsa harus merupakan usaha bersama dari bangsa dan seluruh rakyat yang dilakukan secara gotong royong dan dijiwai oleh semangat kekeluargaan.

c) Asas demokrasi, demokrasi berdasarkan pancasila yang meliputi bidangbidang politik, sosial, dan ekonomi serta yang dalam penyelesaian masalah-masalah nasional berusaha sejauh mungkin menempuh jalan permusyawaratan untuk mencapai mufakat.

d) Asas adil dan merata, bahwa hasil-hasil mateial dan sipiritual yang dicapai dalam pembangunan harus dapat dinikmati merata oleh seluruh bangsa dan bahwa tiap-tiap warga negara berhak menikmati hasil-hasil pembangunan yang layak diperlukan bagi kemanusiaan dan sesuai dengan nilai dharma baktinya yang diberikannya kepada bangsa dan Negara

e) Asas perikehidupan dalam keseimbangan, keseimbangan antara kepentingan - kepentingan, yaitu antara kepentingan keduniaaan dan akhirat, antara kepentingan material dan spiritual, antara kepentingan jiwa dan raga, antara kepentingan individu dan masyarakat, antara kepentingan perikehidupan darat, laut dan udara, serta kepentingan nasional dan internasional.

f) Asas kesadaran hukum, bahwa tiap warga negara Indonesia harus selalu sadar dan taat kepda hukum dan mewajibkan Negara menegakkan dan menjamin kepastian hukum.

g) Asas kepercayaan pada diri sendiri, bahwa pembangunan nasional harus berlandaskan pada kepercayaan akan kemampuan dan kekuatan sendiri, serta bersendikan kepada kepribadian bangsa.

\footnotetext{
12“"Pancasila sumber ideologi bangsa” (http://halil-pkn.blogspot.com/2011/09/bab-1-pancasila-sebagaiideologi.htm) diakses 16 Agustus 2012
} 
h) Asas wawasan nusantara yang mencakup perwujudan kepulauan nusantara sebagai satu kesatuan politik, satu kesatuan sosial budaya, satu kesatuan pertahanan dan keamanan. ${ }^{13}$

Dalam pengertian kesatuan politik tercakup pengertian bahwa seluruh kepulauan nusantara merupakan satu kesatuan hukum, hanya ada satu Hukum Nasional yang mengabdi pada kepentingan nasional

\section{PENUTUP}

\section{Kesimpulan}

1. Kedudukan pancasila dalam sistem hukum Indonesia merupakan sumber dari segala sumber hukum atau sumber tertib hukum sehingga pancasila dijadikan nilai dasar bagi penyusunan norma hukum di Indonesia.

2. Fungsi Pancasila dalam Sistem Hukum Indonesia tercermin dari 5 (lima) sila yang ada dalam pancasila, dimana hal tersebut tercermin dalam kehidupan bermasyarakat untuk mewujudkan masyarakat adil dan makmur, sesuai dengan cita - cita dan tujuan bangsa Indonesia.

\section{Saran}

1. Karena Pancasila merupakan pandangan hidup bangsa, maka sikap bangsa Indonesia pun harus menunjukkan sikap yang saling menghormati satu sama lain, tepo seliro dan tenggang rasa sebagai wujud dari ke-5 sila yang terdapat dalam pancasila.

2. Perwujudan sikap bangsa Indonesia dalam penerapan hukum, adanya sikap tidak ada pandang bulu dan menjauhi sikap diskriminasi, sehingga penegakan hokum dapat tercapai sesuai aturan-aturan yang ada.

\footnotetext{
${ }^{13}$ Sunarjo Wreksosuhardjo, Ilmu Pancasila Yuridis Kenegaraan Dan Ilmu Filsafat Pancasila, Andi Publisher, Yogyakarta, 2009, hal. 54
} 


\section{DAFTAR PUSTAKA}

Dardji Darmodihardjo \& Shidarta, Penjabaran Nilai-Nilai Pancasila Dalam Sistem Hukum Indonesia, PT. Raja Grafindo Persada, 1998

Eka Darmaputera, Pancasila Dalam Identitas Dan Modernitas, BPK Gunung Mulia, 1997

Fahrul Ihsan, Ekonomi Pancasila : Gagasan Dan Kemungkinan, Pustaka LP3ES, Jakarta, 2008

Ilhami Bisri, Sistem Hukum Indonesia : Prinsip-Prinsip Dan Implementasi Hukum DiIndonesia, PT. Rajawali Pers, Jakarta, 2008

Mulyanto, Pancasila Dasar Negara. UGM, Dan Jati Diri Bangsa, Edisi ke-1, Cetakan ke-1, PT. Ghalia, Bandung, 2004

Misbah Ulmunir, Pendidikan Pancasila, Paradigma Yogyakarta, 2006

Slamet Sutrisno, Filsafat Dan Ideologi Pancasila, Andi Publisher, Yogyakarta, 2006

Subandi Al Marsudi, Pancasila Dan UUD '45 Dalam Paradigma Reformasi, PT. Rajawali Pers, Jakarta, 2006

Sunarjo Wreksosuhardjo, Ilmu Pancasila Yuridis Kenegaraan Dan Ilmu Filsafat Pancasila, Andi Publisher, Yogyakarta, 2009

Titon Slamat Kurnia, Pengantar Sistem Hukum Indonesia, Alumni Bandung, 2009 Indonesia, Undang-Undang Dasar 1945

"Pancasila pandangan hidup bangsa"

(http://mudiartana.blogspot.com/2010/02/pancasila-sebagai-pandanganhidup-dan.html) diakses 14 Agustus 2012

"Pancasila sumber ideologi bangsa"

(http://halil-pkn.blogspot.com/2011/09/bab-1-pancasila-sebagai-ideologi.htm) diakses 16 Agustus 2012 